\title{
PELAKSANAAN MUSYAWARAH PERENCANAAN PEMBANGUNAN DESA DI DESA UJUNG MATTAJANG KECAMATAN MAPPEDECENG KABUPATEN LUWU UTARA
}

\author{
Muh. Ryan Pratama, ${ }^{1}$ Fatmawati, ${ }^{2}$ Ruskin Azikin ${ }^{3}$ \\ 1) Jurusan Ilmu Administrasi Negara Unismuh Makassar \\ 2) Jurusan Ilmu Administrasi Negara Unismuh Makassar \\ 3) Jurusan Ilmu Administrasi Negara Unismuh Makassar
}

\begin{abstract}
This researchconcerns on the implementation of conference of village devolvement planning in Ujung Matajang village, Mappedeceng district, North Luwu regency. The objective of this research is know the implementation of conference of village devolvement planning in Ujung Matajang village, Mappedeceng district, North Luwu regency and To find out the obstructive factor in that planning.This research is descriptive-qualitative type.The collection data technique applied were observation, interview, and documentation. The number of informants in this research is eleven people. The result of this research reveals that the implementation of conference of village devolvement planning in Ujung Matajang village, Mappedeceng district, North Luwu regency is running well. It can be proved on two indicators, planning stage and implementation stage.
\end{abstract}

Keyword: conference, planning, village development.

\begin{abstract}
Penelitian ini mengkaji tentang pelaksanaan musyawarah perencanaan pembangunan Desa di Desa Ujung Mattajang Kecamatan Mappedeceng Kabupaten Luwu Utara. Tujuan penelitian ini adalah untuk mengetahui pelaksanaan musyawarah perencanaan pembangunan Desa di Desa Ujung Mattajang Kecamatan Mappedeceng Kabupaten Luwu Utara, Dan untuk mengetahui faktor yang menghambat pelaksanaan musyawarah perencanaan pembangunan Desa. Jenis penelitian ini adalah kualitatif dan data yang digunakan adalah dengan tipe deskriptif, teknik pengumpulan data yang di gunakan dalam penelitian ini adalah observasi, wawancara, dokumentasi. jumlah informan dalam penelitian ini sebanyak 11 orang. Hasil penelitian menunjukan bahwa pelaksanaan musyawarah perencanaan pembangunan Desa di Desa Ujung Mattajang Kecamatan Mappedeceng Kabupaten Luwu Utara. tahapan persiapan, dan tahapan pelaksanaan. kedua indikator ini berjalan dengan baik.
\end{abstract}

Kata Kunci: Musyawarah Perencanaan Pembangunan Desa 


\section{PENDAHULUAN}

Musyawarah

perencanaanpembangunan yang di singkat musrenbang adalah forum antar pelaku dalam rangka menyusun rencana pembangunan nasional dan rencana pembangunan daerah.

Musrenbang digunakan sebagai wadah penyusunan rencana pembangunan nasional, baik di pusat maupun di daerah (UU NO 25 tahun 2004,pasal 1:6) pelaksanaan pembangunan nasional, baik di pusat dan daerah di dasarkan demokrasi dengan prinsip-prinsip kebersamaan berkeadilan, berkelanjutan, berwawasan lingkungan, serta kemandirian dengan menjaga keseimbangan kemajuankesatuan nasional (UU NO.25 tahun 2004, pasal 2:7)

\section{Penerapan prinsip-prinsip} tersebut di atas, dimulai dari proses pembangunan itu sendiri, dalam hal ini penyelengaraan musrenbang. Oleh karena itu, musrenbang melibatkan stake holderdalam masyarakat. Pelaksanaan musrenbang, khususnya di daerah, melibatkan masyarakat, mulai dari tingkat desa/ kelurahan, hingga kabupaten/kota dan provinsi, sebagaimana dikemukakan dalam Keputusan menteri dalam negeri No.050-187/kep/bangda/2007

tentang pedoman penilaiandan Evaluasi pelaksanaan penyelenggaraan musrenbang bahhwa sala satu tujuan musrenbang adalah mendorong pelibatan para pemangku kepentingan dalam proses pengambilan keputusan perencanaan (RKPD).

Evaluasi Pelaksanaan rencana Adalah bagian dari kegiatan perencanaan pembangunan secara sistematis mengumpulkan dan menganalisis data dan informasi untuk menilai pencapaian sasaran, tujuan dan kinerja pembangunan. Evaluasi ini dilaksanakan berdasarkan indikator dan sasaran kinerja yang tercantum dalam dokumen rencanapembangunan.

Musyawarah Perencanaan Pembangunan (Musrenbang) 
memang telah menjadi istilah populer dalam penyelenggaraan pembangunan di daerah dan desa, bersamaan dengan diterbitkannya Undang-Undang Nomor 25 Tahun 2004 tentang Sistem Perencanaan Pembangunan Nsasional. Dalam Pasal 1 ayat (21) Musyawarah Perencanaan Pembangunan yang selanjutnya disingkat Musrenbang diartikan sebagai forum antar pelaku dalam rangka menyusun rencana pembangunan Nasional dan rencana pembangunan daerah.

Sedangkan untuk Musrenbangdesa sendiri dinyatakan dalam Peraturan Menteri Dalam Negeri Nomor 66 Tahun 2007 Pasal 1 ayat (11), yang menyebutkan bahwa Musrenbang desa adalah forum musyawarah tahunan yang dilaksanakan secara partisipatif oleh para pemangku kepentingan desa untuk mencapai rencana kegiatan di desa 5 tahun (RPJM-D) dan 1 tahunan (RKP-D).

PertamaMusrenbang bersifat seremonial. Musrembang sebagai salah satu tempat dialog pembangunan, diskusi dan komunikasi untuk mendapatkan suatu perencanaan pembangunan, di anggap hanya kegiatan rutinitas yang bersipat seremonial, sehingga keterlibatan masyarakat dalam musrembang tidak mendapat perhatian serius. Hal ini sebagaimna dijelaskan W. Ishardino satires (20011:22), bahwa penyelenggaraan musrenbang kerap kurang memperhatikan aspek partisipasi secara luas dan masi terbatas pada serimonial dan acara rutin belaka.

Pelaksanaan Musyawarah Pembangunan desa yang selanjutnya disingkatMusrenbangdes adalah forum musyawarah tahunan stakeholder desa (pihak yangberkepentingan untuk mengatasi permasalahan desanya dan pihak yang akanterkena dampak hasil musyawarah) untuk menyepakati rencana kegiatan tahun anggaran berikutnya (Hanif Nurcholis dalam Rustam Efendi 2010)

Musyawarah Perencanaan Pembangunan (Musrenbang) memang telah menjadi istilah populer dalam penyelenggaraan pembangunan di daerah dan desa, bersamaan dengan diterbitkannya Undang-Undang Nomor 25 Tahun 
2004 tentang Sistem Perencanaan Pembangunan Nsasional. Dalam Pasal 1 ayat (21) Musyawarah Perencanaan Pembangunan yang selanjutnya disingkat Musrenbang diartikan sebagai forum antar pelaku dalam rangka menyusun rencana pembangunan Nasional dan rencana pembangunan daerah.

Menurut Islamey (2015), ciriciri musyawarah dan mufakat antara lain: a). Masalah yang dibicarakan merupakan kepentingan bersama.b). Pembicaraan harus dapat diterima dengan akal sehat dan sesuai hati nurani yang luhurProses musyawarah se c). lalu mempertimbangkan moral.d).Usul atau pendapat mudah dipahami dan masuk akal.e).asil keputusan tidak memberatkanwarga atau rakyat.

Musyawarah Perencanaan Pembangunan (Musrenbang) desa adalah forum musyawarah tahunan para pemangku kepentingan (stakeholders) desa untuk m4wqenyepakati Rencana Kerja Pembangunan Desa (RKP Desa) tahun anggaran yang akan direncanakan. Musrenbang desa dilakukan setiap bulan Januari dengan mengacu kepada dokumen Rencana Pembangunan Jangka Menengah Desa (RPJM Desa).Setiap desa diamanatkan untuk menyusun dokumen rencana 5 tahunan yaitu RPJM Desa dan dokumen rencana tahunan yaitu RKP Desa.

Musrenbang adalah forum perencanaan program yang diselenggarakan oleh lembaga publik, yaitu pemerintah desa, bekerjasama dengan warga dan para pemangku kepentingan lainnya. Musrenbang yang bermakna akan mampu membangun kesepahaman tentang kepentingan dan kemajuan desa, dengan cara memotret potensi dan sumber-sumber pembangunan yang tersedia baik dari dalam maupun luar desa.

Musyawarah Perencanaan Pembangunan yang sering kita kenal dengan sebutan Musrenbang, adalah sarana pemerintah disemua tingkatan, untuk menghimpun aspirasi pembangunan disemua bidang kehidupan masyarakat. Menurut KEPMEN BANGDA No.050-187/Kep/Bangda- /2007: Musrenbang atau MusyawarahPerencanaan Pembangunan 
adalah forum antar pelaku dalam rangka menyusun rencana pembangunan nasional dan rencana pembangunan daerah.

Menurut Siagian dalam Aisyah Oktaviani Putri (2015) Musrenbang merupakan forum konsultasi para pemangku kepentingan untuk menghasilkan kesepakatan perencanaan pembangunan di daerah yang bersangkutan sesuai tingkatan wilayahnya. Penyelenggaraan musrenbang meliputi tahap persiapan, diskusi dan perumusan prioritas program/kegiatan, formulasi kesepakatan musyawarah dan kegiatan pasca musrenbang.

Perencanaan pembangunan dapat diartikan sebagai proses perumusan alternatif-alternatif yang berdasarkan data-data yang digunakan sebagai bahan untuk melaksanakan suatu kegiatan kemasyarakatan (Riyadi dalam Fikri Azhar 2015).

Perencanaan pembangunan merupakan suatu pengarahan penggunaan sumber-sumber pembangunan (termasuk sumber ekonomi) yang terbatas adanya, untuk mencapai tujuan-tujuan keadaan sosial ekonomi yang lebih baik secara lebih efektif dan efisien (Tjokroamidjojo dalam Fikri Azhar 2015).Bentuk perencanaan pembangunan yang bersifat bottom up sudah terlaksana dengan baik. Hanya saja belum terimplementasi sesuai dengan apa yang menjadi keinginan dan kebutuhan masyarakat. Hal ini dikarenakan pada tahapan yang lebih tinggi yaitu Musrenbang Kabupaten, prioritas usulan yang disampaikan oleh masing-masing desa/kelurahan harus disinkronkan dengan program pembangunan SKPD yang bersifat top down.(Utin Sri Ayu dalam Anak Agung NgurahAritama 2016).

Menurut safrijal dalam Wiyasti Dwiandini (2013) menyatakan bahawa perencanaan pembangunan adalah suatu kumpulan kebijakan dalam program pembangunan untuk merangsang masyarakat dan swasta untuk menggunakan sumber daya yang tersedia secara lebih produktif. Sedangkan menurut Riadi dalam Wiyasti Dwiandini mengatakan bahwa perencanaan pembangunan dapat diartikan 
sebagai suatu proses perumusan alternatife-alternatife atau keputusankeputusan yang didasarkan pada data-data dan fakta-fakta yang akan digunakan sebagai bahan untuk melaksanakan suatu rangkaian kegiatan atau aktifitas kemasyarakatan, baik yang bersifat fisik (material) maupun non fisik (mental dan spiritual) dalam rangka mencapai tujuan yang lebih baik.

Sumaryadi

dalam

Yudhiansyah Eka Saputra (2015)

Pembangunan partisipatif merupakan pendekatan pembangunan yang sesuai dengan hakikat otonomi daerah yang meletakkan landasan pembangunan yang tumbuh berkembang dari masyarakat, diselenggarakan secara sadar dan mandiri oleh masyarakat dan hasilnya dinikmati oleh seluruh masyarakat.

Melalui program-program pembangunan partisipatif tersebut diharapkan semua elemen masyarakat dapat secara bersamasama berpartisipasi dengan cara mencurahkan pemikiran dan sumberdaya yang dimiliki guna memenuhi kebutuhannya sendiri.
Jenseen

dalam

GustiZulkarnainTompo(2015)

merekomendasi bahwa perencanaan pembangunandaerah harus memperhatikan hal-hal yang bersifat kompleks, sehingga prosesnya harus memperhitungkan kemampuan sumber daya yang ada,baik sumber daya manusia, sumber daya alam, sumber daya fisik, dansumber daya lainnya.

Menurut Hetifa $\mathrm{Sj}$ Sumarto dalam Anggita Pernama Putri (2009) menyatakan musrembang sebgai wadah silahturahmi masyarakat anatar masyarakat dengan pemerintah dan antara masyarakat dengan stakeholder pembangunan lainnya untuk mendapatkan keserasian anatar kebijakan pembangunan yang ada serta untuk menjaring aspirasi semua pemangku kepentingan.

Masri Singaribun dalamRustam Efendi (2010) indikator-indikator Pelaksanaan Musyawarah yang memberikan bagaimana cara mengukur suatu pelaksanaan musyawarah pada tingkat desa sehingga pengukuran tersebut dapat diketahui apa saja 
yang menjadi pendukung untuk Perencanaan Pembangunan (Musrenbang) adalah sebagai berikut:1). Tahapan Persiapan 2). Tahapan Pelaksanaan

\section{METODE PENELITIAN}

Penelitian ini direncanakan akan berlangsung selama 2 bulan, mulai tanggal 10 agustus -10 oktober 2017 dan berlokasi di Desa Ujung Mattajang Kecamatan Mappedeceng Kabupaten Luwu Utara. Alasan pemilihan lokasi ini didasarkan karena Desa Ujung Mattajang sedang mengalami pembangunan infrastruktur tetapi mengalami masalah kurangnya Pelaksanaan yang tidak diakomodir dalam pelaksanaan rencana pembangunan dengan organisasi masyarakat.

Adapun jenis dan tipe penelitian yaitu: Jenis penelitian ini adalah penelitian deskriptif kualitatif yaitu suatu metode penelitian yang dilakukan dengan tujuan utama untuk membuat gambaran tentang suatu kegiatan secara objektif, wawancara, catatan lapangan, foto, video tape, dokumen pribadi, catatan atau memo dan dokumen resmi lainya. sumber data yang digunakan terdiri atas dua yaitu data primer dan data sekunder. Informan penelitian yakni: Jumlah informan sebanyak 10 orang. Ada pun teknik dalam pengumpulan data yang dilakukan yakni Metode pustaka, observasi dan wawancara. Teknik analisa data yang digunakan dalam penelitian ini adalah model analisa interaktif yaitu reduksi data, sajian data dan penarikan kesimpulan. Keabsahan data yang digunakan adalah triangulasi sumber, triangulasi metode dan triangulasi waktu.

\section{HASIL DAN PEMBAHASAN}

Desa Ujung Mattajang Kecamatan Mappedeceng di Kabupaten Luwu Utara, Provinsi Sulawesi Selatan. Desa Ujung Mattajang dengan luas wilayah sebesar 275,50 km2 merupakan Desa Ujung Mattajang yang berbatasan langsung dengan Kecamatan Masamba di bagian barat yang merupakan ibukota dari Kabupaten Luwu Utara. Desa Ujung Mattajang ini secara geografis terletak pada $2^{\circ}$ 23 ' 55”- 2० 41' 54” Lintang Selatan dan $120^{\circ} 21^{\prime} 9^{\prime \prime}-120^{\circ} 32^{\prime}$ 40” Desa Ujung Mattajang sebanyak 
terbagi 4 dusun yaitu dusun galinggang, dan dusun kande api.

Berdasarkan jumlah penduduk di Desa Ujung Mattajang adalah yang terbanyak di antara Desa yang ada di wilayah Desa Ujung Mattajang yaitu sebanyak 3.236 jiwa disusul kemudian Desa Kapidi dengan jumlah penduduk sebanyak 2.504 jiwa, sedangkan Desa yang memiliki penduduk paling sedikit adalah Desa Sumberwangi dengan jumlah penduduk sebanyak 452 jiwa.Dengan luas wilayah 275,50 km2, Desa Ujung Mattajang memiliki kepadatan penduduk sebesar 83 jiwa/km2, di mana Desa Cendana Putih II memiliki kepadatan terbesar yaitu sekitar 442 jiwa/km2 jauh di atas desadesa lainnya.Pada tahun 2014, jumlah penduduk Desa Ujung Mattajang sejumlah 22.884 jiwa ,mencakup 5.655 rumah tangga yang tersebar di 15 desa. Rata-rata anggota rumah tangga di setiap desa adalah 4 orang. Jumlah rumah tangga terbanyak ada di Desa Ujung Mattajang sebanyak 713 rumah tangga.Sedangkan yang paling sedikit ada di desa Sumber Wangi, sebanyak 110 rumah tangga.Jumlah ART (anggota rumah tangga) terbanyak ada di desa Benteng, yakni sebanyak 5 orang. Sedangkan ART paling sedikit ada di desa Sumber Harum dan Hasanah, yakni sebanyak 3 orang.

Pada Tahun 2014, Desa Ujung MattajangKecamatan Mappedeceng memiliki 17 Taman Kanak-Kanak, $17 \quad$ Sekolah Dasar/Sederajat, 6 SLTP/Sederajat, dan 3 SMA/Sederajat. Jumlah Taman Kanak-Kanak tahun 2014 tidak mengalami perubahan dibanding tahun sebelumnya yakni 17 Taman Kanak-kanak sedangkan untuk tingkat pendidikan SLTA tidak mengalami peningkatan di banding tahun sebelumnya dimana pada tahun sebelumnya hanya terdapat 3 buah SLTA dan jumlah Sekolah Dasar 17 buah tidak mengalami peningkatan dibanding tahun sebelumnya demikian pula dengan SLTP hanya terdapat 6 buah.

Institusi penanggung jawab kesehatan Desa Ujung Mattajangdi Kecamatan Mappedeceng adalah UPDTCandana Putih Dua dengan dukungan sarana 1 Puskesmas Rawat 
Jalan yang terletak di desa Cendana Putih Dua dan 14 Puskesmas Pembantu yang terdapat disetiap desa Pelaksanaan Musyawarah Perencanaan Pembangunan Desa (Musrenbangdes) Di Desa Ujung Mattajang Kecamatan Mappedeceng Kabupaten Luwu Utaramerupakan suatu forum musyawarah tahunan seluruh pemangku kepentinganyang ada di desa untuk menyepakati rencana kegiatan tahun anggaran berikutnyayang kemudian diajukan kepada Musyawarah Perencanaan (Musrenbang) padatingkat yang telah diberikatan oleh aparat desa.

Tahapan Persiapan merupakan tahapan Pengambilan keputusan dalam suatu pemilihan alternatif yang dilakukan dalam musrembang desa. Dan tahapan persiapan dalam Pengambilan keputusan merupakan sebuah pendekatan yang sistematis terhadap sebuah hakikat alternatif yang dihadapi dan mengambil suatu tindakan yang menurut perhitungan atau suatu tindakan yang paling tepat dalam musrembang desa yang dilakukan di Desa Ujung Mattajang Kecamatan Mappedeceng Kabupaten Luwu Utara. penetapan jadwal pelaksanaan musrembang merupakan penetapan jadwal dalam sebuah kegiatan pengalokasian sumber-sumber kegiatan musrembang yang ada untuk menjalankan sekumpulan kegiatan apa yang telah direncanakan dalam sebuah kegiatan. Penetapan penjadwalan merupakan suatu kegiatan yang memasuki sejumlah kegiatan-kegiatan yang telah direncanakan dalam sebuah kegiatan musrembang. Dan dimana penetapan jadwal pelaksanaan musrembang ini rencana pengaturan dalam kegiatan musrembang agar kegiatan yang dilakukan dapat menghasilkan pengalokasian sumber, baik waktu maupun fasilitas dalam kegiatan musrembang dan penetapan jadwal pelaksanaan musrembang dimana kegiatan perencanaan berupa pengaloksian sumber maupun tenaga masyarakat dalam mengikuti pelaksanaan musyawarah perencanaan musrembang desa.Berdasarkan hasil diatas dapat diperoleh jawaban bahwa penetapan jadwal pelaksanaan musrembang yang dilakukan di Desa Ujung Mattajang Kec. Mappedeceng Kab.

Website : http://journal.unismuh.ac.id/index.php/kolaborasi 
Luwu Utara sangatlah menentukan sebuah kegiatan kapan akan dilaksanakan kegiatan tersebut dan dapat berlangsung sesegera mungkin untuk memulai daftar kegiatan yang diprioritaskan yang akan dilaksanakan oleh desa dan dimana masyarakat juga diperlukan dalam penetapan jadwal untuk membahas kegiatan yang akan di selenggarakan di kantor desa.

Berdasarkan hasil atau observasi peneliti lakukan maka peneliti menyimpulkan bahwa untuk melakukan penetapan jadwal pelaksanaan musrebang memang harus dilakukan sesegera mungkin karna dimana penetapan jadwal yang baik akan mendapatkan hasil kegiatan prioritas yang baik pula . Dan dimana akan dilaksanakan oleh desa dan para aparat desa dalam memberi tahukan masyarakat yang mengikuti kegiatan musrembang desa dalam memusyawarakan adanya kegiatan yang akan dilaksanakan di desa ujung mattajang. Tempat pelaksanaan musrembangdes merupakan tempat yang diselenggarakan oleh panitia pelaksanaan kegiatan musrembang di
Desa Ujung Mttajang. Dan dimana tempat ini merupakan suatu aktifitas untuk melakukan berbagai kegiatan yang akan dilaksanakan oleh peserta musrembang. Tempat merupakan komitmen sumber daya jangka panjang yang dapat mengurangi fleksibilitas masa depan kegiatan, tempat juga mempengaruh berlangsung kegiatan yang akan dilaksnakan dalam pelaksanaan musyawarah perencanaan musrembang di Desa Ujung Mattajang Di Kec. Mappedeceng. Berdasarkan hasil diatas dapat diperoleh jawaban bahwa tempat pelaksanaan musrembang begitu sangat menentukan berjalannya suatu kegiatan yang akan dilaksanakan dalam melakukan berbagai kegiatan yang ada didesa. Dan tempat pelaksanaan ini seperti ruangan aula yang akan di gunakan dalam kegiatan haruslah cukup besar agar peserta musrembang tidak begitu padat dalam ruangan aula tersebut. Penetapan calon peserta musrebang Desa merupakan penetapan untuk siapa yang akan bertanggung jawab dalam mengambil satu kegiatan yang akan dilaksanakan, dan adanya 
penetapan calon peserta musrembang berbagai kegiatan yang akan dilakukan dalam pelaksanaan msyawarah perencanaan musrembang yang akan di adakan di aula Kantor Desa. Para setiap calon peserta musrembang ini memiliki masing-masing tugas kegiatan yang akan diberika kepada calon peserta musrenbang.

Berdasarkan hasil wawancara dapat di peroleh jawaban bahwa dalam pelaksanaan musyawarah perencanaan musrembang ini masyarakat yang ikut dalam kegiatan musrembang mulai berantusias dalam menjalankan kegiatankegiatan yang dilaksanakan di Desa Ujung Mattajang. Calon peserta ini juga harus semangat dalam menjalankan kegiatan yang diberikan kepada, karna tanggung jawab yang diberkan kepada calon peserta sangat besar untuk dapat menyelesaikan tugas yang diberikan kepadanya.

Pembuatan kegiatan-kegiatan pembangunan Desa merupakan hakekat dalam perencanaan pembangunan yang secara sadar, terorganisasi, dan terus menerus dilakukan memilih alternatif yang terbaik dari sejumlah alternatif untuk mencapai tujuan tertentu. Dalam rangka menyusun langka-langka untuk memastikan pencapian suatu kegiatan pembangunan harus dalam proses pencapain tujuan yang diinginkan. Pembuatan kegiatankegiatan dalam pembangunan musrembang ini dugunakan sebagia suatu alat untuk mencpai tujuantujuan perubahan masyarakat secara lebih baik.

Berdasarkan hasil wawancara dapat di peroleh jawaban bahwa dalam pelaksanaan musyawarah perencanaan musrembang ini masyarakat dapat melkukan pencapai tujuan kegiatan tanpa adanya suatu kendala dalam menjalankan suatu kegiatan. Dimana suatu pembuatan kegiatan harus diliahat sejauh mana akan dilaksanakan kegiatan musrembang tersebut.

Rencana kerja pemerintah Desa merupakan salah satu rencana yang dapat mengembangkan pelaksanaan musyawarah perencnaan Desa yang akan dijalankan dalam sebuah kegiatan-kegiatan musrembang Desa. Rencana kerja pemerintah dimaknai sebaggai proses persiapan secara 
sistematis kegiatan - kegiatan pelaksanaan musyawarah perencanaan Desa dan dimana akan dilakukan pencapaian tujuan kerja pemerintah Desa yang dipilih secara sadar atas dasar skala kebutuhan dan nilai-nilai yang dimiliki oleh masyarakat dalam pelaksanaan musyawarah perencanaan Desa Ujung Mattang.

Berdasarkan hasil wawancara dapat di peroleh jawaban bahwa dalam pelaksanaan musyawarah perencanaan musrembang Desa ini dapat terliahat adanya rencana kerja pemerintah desa yang akan berlangsung di Desa Ujung mattang dan rencana kerja pemerintah ini dapat terliahat dengan baik dan pemerintah Desa juga menyusun rencana kerja yang sistematis untuk dapat diberitau kepada elemen masyarakat yang akan hadir di pelaksanaan musyawarah perencanaan musrembang Desa Ujung Mattang.

Rencana kerja pemerintah Desa merupakan salah satu rencana yang dapat mengembangkan pelaksanaan musyawarah perencnaan Desa yang akan dijalankan dalam sebuah kegiatan-kegiatan musrembang Desa. Rencana kerja pemerintah dimaknai sebaggai proses persiapan secara sistematis kegiatan - kegiatan pelaksanaan musyawarah perencanaan Desa dan dimana akan dilakukan pencapaian tujuan kerja pemerintah Desa yang dipilih secara sadar atas dasar skala kebutuhan dan nilai-nilai yang dimiliki oleh masyarakat dalam pelaksanaan musyawarah perencanaan Desa Ujung Mattang.

Dalam Pelaksanaan Musyawarah Perencanaan Pembangunan Desa Di Ujung Mattajang Kec. Mappedeceng Kab. Luwu Utara. Ada faktor yang mendukung dan menghambat terjadinya Pelaksanaan Musyawarah Perencanaan Pembangunan Desa. Faktor-faktor ini di hadapi dalam Pelaksanaan Musyawarah Perencanaan Pembangunan Desa Di Ujung Mattajang Kec. Mappedeceng Kab. Luwu Utara. 1. Faktor Pendukung Pelaksanaan Musya- warah Perencanaan Pembangunan

Desa Di Ujung Mattajang Kec. Mappedeceng Kab. Luwu 
Utara. a. Adanya Dukungan Pemerintah

Dukungan pemerintah yang dimaksud disni adalah pemberian dorongan motivasi atau semangat serta nasehat kepada masyarakat lain. Dukungan pemerintah dalam pelaksanaan musyawarah perencanaan pembangunan desa dimana pemerintah memberikan sarana dan prasarana di pelaksanaan musyawarah perencanaan pembangunan desa. Dan adanya dukungan pemerintah dalam pelaksanaan musyawarah perencanaan pembangunan desa maka desa yang melakukan kegiatan pelaksanaan mendapatkan sarana dan prasarana dari pemerintag.

Berdasarkan hasil wawancara yang peneliti lakukan dapat disimpulkan bahwa dukungan pemerintah dalam pelaksanaan musyawarah perencanaan pembanguna Desa adanya kerja sama dengan pemerintah dalam rangka pelaksanaan musyawarah perencanaan pembangunan Desa ini sangat dapat meningkatkan pertumbahan pembangunan desa secara merata. Dan adanya berbagai sarana dan prasarana yang diberikan oleh pemerintah. b. Adanya Hubungan Kerjasama dengan Pemerintah Desa Adanya hungan kerjasama dengan pemerintah merupakan salah satu faktor pendukung efektifitas fungsih badan permusyawaratan Desa (BPD) adalah terciptanya hubungan yang harmonis anatar BPD dengan pemerintah Desa dengan senantiasa menghargai dan menghormati satu sama lain, serta adanya niat baik untuk saling membantu dan saling mengingatkan. Dalam pelaksanaan musyawarah perencanaan pembangunan Desa memang harus ada hungan kerjasama dengan pemerintah desa agar semua kegiatan yang dilakukan berjalan dengan baik kerna adangan hungan kerjasama dengan pemerintah atau dengan masyarakat.

Partisipasi anggota rapat yang masi kurang merupakan suatu partisipasi dari sebagian kalangan yang tidak ikut melakukan kegiatan partisipasi dan Partisipasi Badan Permusyawaratan Desa (BPD) dalam rapat pembahasan aspirasi-aspirasi dalam pelaksanaan musyawarah perencanaan pembangunan Desa 
yang disampaikan oleh masyarakat sangatlah penting, karena keaktifan mereka dapat memberikan pengaruh besar tehadap tercapainya aspirasi yang diberikan atau terwujudnya suatu pelaksanaan kegiatan dalam perencanaan pembangunan Desa Ujung Mattajang. b. Adanya Hubungan Kerjasama dengan Pemerintah Desa

Adanya hungan kerjasama dengan pemerintah merupakan salah satu faktor pendukung efektifitas fungsih badan permusyawaratan Desa (BPD) adalah terciptanya hubungan yang harmonis anatar BPD dengan pemerintah Desa dengan senantiasa menghargai dan menghormati satu sama lain, serta adanya niat baik untuk saling membantu dan saling mengingatkan. Dalam pelaksanaan musyawarahperencanaan pembangunan Desa memang harus ada hungan kerjasama dengan pemerintah desa agar semua kegiatan yang dilakukan berjalan dengan baik kerna adangan hungan kerjasama dengan pemerintah atau dengan masyarakat.
1. Faktor Pendukung Pelaksanaan Musyawarah Perencanaan Pembangunan Desa Di Ujung Mattajang Kec. Mappedeceng Kab. Luwu Utara.

a. Adanya Dukungan Pemerintah Dukungan pemerintah yang dimaksud disni adalah pemberian dorongan motivasi atau semangat serta nasehat kepada masyarakat lain. Dukungan pemerintah dalam pelaksanaan musyawarah perencanaan pembangunan desa dimana pemerintah memberikan sarana dan prasarana di pelaksanaan musyawarah perencanaan pembangunan desa. Dan adanya dukungan pemerintah dalam pelaksanaan musyawarah perencanaan pembangunan desa maka desa yang melakukan kegiatan pelaksanaan mendapatkan sarana dan prasarana dari pemerintag.

$$
\text { hasil wawancara dapat }
$$
disimpulkan bahwa, salah satu kendala yang dihadapi oleh pihak pelaksanaan musyawarah perencanaan pembangunan Desa saat ini adalah kurang berpartisipasinya anggota-anggota pelaksanaan musyawarah perencanaan pembangunan Desa dalam rapat yang telah 
diadakan oleh pihak pelaksanaan musyawarah perencan- aan pembangunan Desa. Hal tersebut sangat mempengaruhi keefektifan hasil rapat yang ada karena dapat dikatakan bahwa tidak semua dari pihak pelaksanaan musyawarah perencanaan pembangunan Desa berperan dan melaksanakan fungsinya secara aktif

2. Faktor Penghambat Dalam Pelaksanaan Musyawarah Perencan aan Pembangunan Desa Di Ujung Mattajang Kec. Mappedeceng Kab. Luwu Utara.a. Partisipasi Anggota Rapat Yang Masih Kurang.

Partisipasi anggota rapat yang masi kurang merupakan suatu partisipasi dari sebagian kalangan yang tidak ikut melakukan kegiatan partisipasi dan Partisipasi Badan Permusyawaratan Desa (BPD) dalam rapat pembahasan aspirasi-aspirasi dalam pelaksanaan musyawarah perencanaan pembangunan Desa yang disampaikan oleh masyarakat sangatlah penting, karena keaktifan mereka dapat memberikan pengaruh besar tehadap tercapainya aspirasi yang diberikan atau terwujudnya suatu pelaksanaan kegiatan dalam perencanaan pembangunan Desa Ujung Mattajang.

\section{KESIMPULAN}

Berdasarkan data hasil penelitian dan pembahasan yang telah di uraikan pada bab sebelumnya maka penulis dapat mengambil kesimpulan bahwa:

Tahapan Persiapan merupakan tahapan Pengambilan keputusan dalam suatu pemilihan alternatif yang dilakukan dalam musrembang desa. dan tahapan yang telah dipersiapan dalam Pengambilan keputusan adalah merupakan sebuah pendekatan yang sistematis terhadap sebuah hakikat alternatif yang dihadapi dan mengambil suatu tindakan yang menurut perhitungan atau suatu tindakan yang paling tepat dalam musrembang desa yang dilakukan di Desa Ujung Mattajang Kecamatan Mappedeceng Kabupaten Luwu Utara. (a). penetapan jadwal pelaksanaan musrembang dimana para aparat yang bertugas di kantor desa membuat penjadwalan untuk melakukan kegiatan-kegiatan musrembang yang akan dilaksanakan. Dan penetapan jadwala ini harus diselesaikan tepat waktu 
tanpa ada pengunduran waktu lagi, karna kegiatan musrembang harus diprioritaskan dalam sebuah kegiatan tersebut. (b). Tempat pelaksanaan musrembang di desa tidak begitu terjadi kendala dalam menentukan tempat pelaksanaan kegiatan musrebang. Dan dimana tempat pelaksanaan ini telihat pada pelaksanaan Musyawarah Perencanaan Pembangunan Desa (Musrenbangdes) setiap tahunnya tempat yang digunakan adalah ruangan aula Kantor Kepala Desa Ujung Mattajang Kec. Mappedeceng. Dan dimana alon peserta ini memiliki tanggung jawab masingmasing dalam pemberian tugas kegiatan pelaksanaan musyawarah perencanaan musrembang di Desa Ujung Mattajang Kec. Mappedeceng Kab. Luwu Utara.Saran, dari beberapa kesimpulan diatas, penulis mengutip beberapa saran sebagai berikut:

Pelaksanaan musyawarah perencanaan pembangunan Desa atau Musrembang bersifat seremonial. Musrembang sebagai salah satu tempat dialog pembangunan, diskusi dan komunikasi untuk mendapatkan suatu perencanaan pembangunan.Penulis berharap semoga hasil dari penelitian ini bisa bermanfaat dan untuk peneliti selanjutnya supaya lebih baik lagi dari sebelumnya sehingga dalam melakukan penelitian terdapat data yang baru untuk di jadikan sebagai Referensi penelitian selanjutnya. 
Kolaborasi : Jurnal Administrasi Publik, April $2018 \quad$ Volume 4 Nomor 1

\section{DAFTAR PUSTAKA}

Azhar,

fikri.

2015.

Partisipasimasyarakatdalam

musyawarahperencanaan

pembangunan (musrenbang)

dikelurahanpegiriankecamat

ansemampir kota surabaya.

Program

studiilmuadministrasi

negara,

fisip,

universitasairlangga.

Rustam, efendi. 2010. Analisis musyawarah perencanaan pembangunan desa (musrenbangdes) di desa mayang pongkai kecamatan kampar kiri tengah kabupaten kampar. Program studi administrasi negara, fakultas ekonomi dan ilmusosial universitas islam negari sultan syarif kasim.

Yudhiansyah, eka, saputra. (2015).

Partisipasimasyarakatdalam

program pembangunan

desa(kasus: program alokasi

dana desa).departemensains

komunikasi

dan

pengembanganmasyarakatfakul

tasekologimanusiainstitutperta

nian bogor.
Rustam, efendi. 2010. Analisis musyawarah perencanaan pembangunan desa (musrenbangdes) di desa mayang pongkai kecamatan kampar kiri tengah kabupaten kampar. Program studi administrasi negara, fakultas ekonomi dan ilmusosial universitas islam negari sultan syarif kasim.

Gusti, zulkarnain,tompo. .analisisperananbappedadalam pembangunan di kabupatenjeneponto. Program studiilmupemerintahanfakultasilmusosial dan ilmupolitikuniversitashasanudd inmakassar.

Anggita, pernama ,putri . (2009). Partisipasiperemupandalam perencanaan pembangunan partisipatif.Jurusanilmuadmi nistrasi. Fakultasilmusosial dan ilmupolitikuniversitassebelas maretsurakarta.

Aisyah,oktaviani,putri.(2015).

Partisipasimasyarakatdalam musyawarahperencanaan pembangunan $d i$

Website : http://journal.unismuh.ac.id/index.php/kolaborasi 


\begin{tabular}{|c|c|c|}
\hline & kelurahanseiputih tengah & Johan,Pamungkas.2015.Pelaksan- \\
\hline & kecamatan medan petisah & aanMusyawarahUntukMufa \\
\hline & kota medan.jl. Kolam no.1 & katDalamRapatKarangTaru \\
\hline & kampus $\quad$ fisipol & na. \\
\hline & progamstudiadministrasipubl & StudiKasusPadaKarangTaru \\
\hline & ikuniversitas medan area. & naSumberCahayaDidukuhSu \\
\hline Azhar, & 2015. & mberejoDesaPatihanKecam \\
\hline & Partisipasimasyarakatdalam & atanSidoharjoKabupatenSra \\
\hline & musyawarahperencanaan & gen.Fakultas \\
\hline & pembangunan (musrenbang) & Keguruan \\
\hline & $d i$ & IlmuPendidikanUniversitas \\
\hline & kelurahanpegiriankecamatan & Muhammadiyah Surakarta. \\
\hline & semampir kota surabaya. & Undang - undangnomor 25 tahun \\
\hline & Program & 2004. \\
\hline & studiilmuadministrasi negara, & Tentangpelaksanaanmusremb \\
\hline & fisip, universitasairlangga. & angdesa. \\
\hline
\end{tabular}

Wiyasti, dwiandini. (2013).

Efektifitaspelayananmusya-

warahperencanaanPembang-

unnan (musrembang)

dalampenyusunanrencanaangg

aranpendapatan dan

belanja daerah (rpbd) kota

administrasi jakarta timur.

Program ilmuadministrasi

negara. Fakultasilmusosial dan

ilmupolitikuniversitas

indonesia.

Website : $\underline{\text { http://journal.unismuh.ac.id/index.php/kolaborasi }}$ 